\title{
Population structure and growth of the hermit crab Pagurus brevidactylus (Anomura: Paguridae) from the northern coast of São Paulo, Brazil
}

\author{
F.L. Mantelatto* ${ }^{\int}$, R.A. Christofoletti ${ }^{\dagger}$ and W.C. Valenti ${ }^{\ddagger}$ \\ *Departamento de Biologia, FFCLRP, Universidade de São Paulo (USP), Av. Bandeirantes, 3900, GEP 14.040-901, Ribeirão Preto, \\ São Paulo, Brazil. ${ }^{\dagger}$ Campus do Litoral Paulista, Unidade São Vicente, Universidade Estadual Paulista (UNESP), CEP 11330-900, \\ São Vicente, São Paulo, Brazil. ${ }^{\ddagger}$ Departamento de Biologia Aplicada, FGAV, Universidade Estadual Paulista (UNESP), \\ CEP 14884-900, Jaboticabal, São Paulo, Brazil. `Corresponding author, e-mail: flmantel@usp.br
}

\begin{abstract}
The hermit crab Pagurus brevidactylus (Crustacea: Anomura: Paguridea) from the infralittoral area of Anchieta Island, Ubatuba, was characterized by population structure (size, sex ratio, reproduction and recruitment) and growth. Animals were collected monthly during 1999 by SGUBA diving. A total of 1525 individuals was collected (633 males and 892 females), 695 of them were ovigerous females. Overall sex ratio was 0.7:1 in favour of females. The crabs showed a unimodal distribution with males significantly larger than females. Ovigerous females were collected during all months and in high percentages from $1.0 \mathrm{~mm}$ of shield length, demonstrating intense and continuous reproduction. The longevity was approximately 24 months for males and 18 for females, which showed larger growth rate and reached sexual maturity earlier (two months) than males. The low number of males in this population may be due to the longer life span. Moreover, the sexual dimorphism favours males during the intra- and interspecific fights by shell, food, reproduction and territory. Females demonstrated a short life cycle and intense reproduction.
\end{abstract}

Pagurus brevidactylus (Stimpson, 1859) is a small abundant hermit crab found in the infralittoral zone of Anchieta Island (Mantelatto \& Garcia, 2002), as well as in the northern coast of São Paulo State. The biological aspects of this species in the western Atlantic region are poorly known (Mantelatto \& Meireles, 2004). Therefore, the objective of the present study was to describe the population structure (size, sex ratio, reproduction and recruitment) and the growth in the field of the population inhabiting Anchieta Island, Brazil.

Hermit crabs were collected monthly from January to December 1999 in the infralittoral area of Anchieta Island $\left(23^{\circ} 32^{\prime} \mathrm{S} 45^{\circ} 04^{\prime} \mathrm{W}\right)$, which is an ecological reserve of the northern coast of São Paulo State, Brazil. Animals were collected in the daytime by two people during 30 minutes of SCUBA diving.

Animals were frozen and transported to the laboratory where they were removed from their shells and immediately weighed. Sex was determined from the gonopore position; the presence of eggs at the pleopods determined ovigerous females, being the maturity of males and females based on the size of the smallest ovigerous females. Shield length (SL, from the tip of the rostrum to the $\mathrm{V}$-shaped groove at the posterior edge), measured under a compound light microscope equipped with a camera lucida $(50 \times)$, was the measurement of size of the hermit crabs.

Hermit crabs were grouped in size-classes of $0.2 \mathrm{~mm} \mathrm{SL}$, and the sex ratio for each was calculated. The reproductive period was evaluated by percentage of ovigerous females relative to the total number of females collected monthly. The KolmogorovSmirnov test was used to verify the normality of the sizefrequency distribution of the individuals and the Pearson correlation to test for a correlation between the water temperature and the total of individuals collected monthly or the percentage of ovigerous females. The $\chi^{2}$-test was used to evaluate the sex ratio and an unpaired $t$-test to compare the mean size of males and females.
For growth analysis, the modal shield length of each cohort was obtained from the size-frequency distribution at three month intervals. The von Bertalanffy model was used to determine growth for each sex by means of the Ford-Walford method using CAJUS software. The growth rate equation $\left(\mathrm{V}_{\mathrm{T}}\right)$ was derived by using the expression of von Bertalanffy, resulting in: $\mathrm{V}_{\mathrm{T}}=\mathrm{k}\left(\mathrm{L}_{\infty}-\mathrm{L}_{\mathrm{t}}\right)$ (Valenti et al., 1993). The weight growth curve was fitted by a deductive method using von Bertalanffy's model and the regression coefficient of the weight/shield length relationship (R.A. Christofoletti \& F.L. Mantelatto, unpublished data).

A total of 1525 individuals was collected, $633(41.5 \%)$ were males, $892(58.5 \%)$ were females and $695(45.6 \%)$ of them were ovigerous females. There was an unimodal size distribution for each sex and only males had a normal distribution $(P>0.05)$. Sexual dimorphism was observed in that males reached larger sizes than females. The mean size of males ( $\mathrm{SL}=1.94 \pm 0.36 \mathrm{~mm}$ ) was significantly larger than ovigerous females $(\mathrm{SL}=1.74 \pm 0.26 \mathrm{~mm}$ ) and both were significantly larger than non-ovigerous females $(\mathrm{SL}=1.57 \pm 0.28 \mathrm{~mm}) \quad(P<0.001)$. Shield size varied between 0.91 and $3.16 \mathrm{~mm}$ for males, 1.01 and $2.46 \mathrm{~mm}$ for non-ovigerous females and 1.06 and $3.19 \mathrm{~mm}$ for ovigerous females (minimum and maximum SL, respectively).

Overall sex ratio was 0.7:1 in favour of females and was significantly different from the expected $1: 1 \quad(P<0.01)$. Females were dominant in the smaller size-classes (approximately 70\%), while the percentage of males became progressively larger after $1.8 \mathrm{~mm}$ of SL.

Ovigerous females were collected during all months and in high percentages $(>70 \%$ in all months), demonstrating intense and continuous reproduction in this region. No significant correlation $(P>0.05)$ was observed between water temperature and percentage of ovigerous females. The smallest female $(1.01 \mathrm{~mm}$ SL) belonged to the second size-class $(1.0-1.2 \mathrm{~mm}$ of $\mathrm{SL})$, whereas approximately $50 \%$ of the females were ovigerous and 

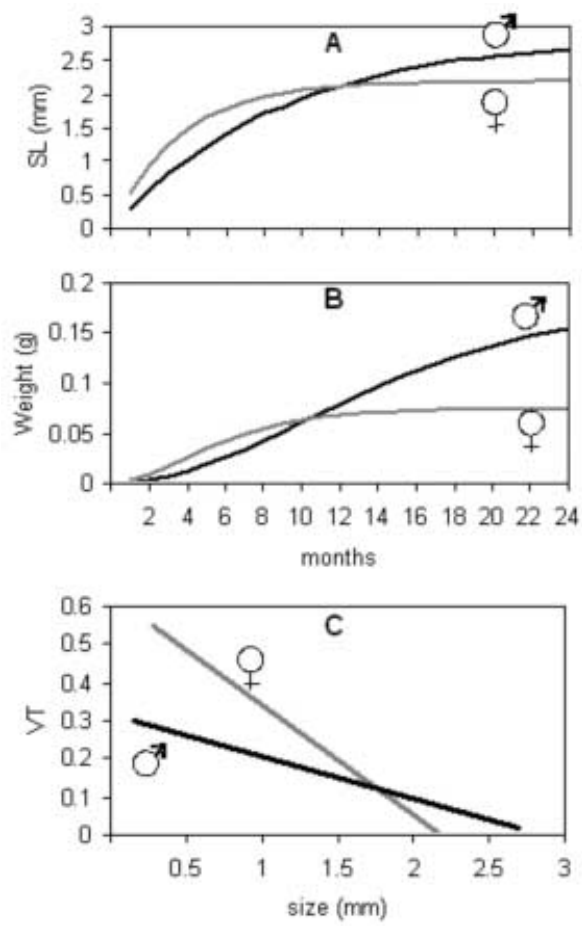

Figure 1. Pagurus brevidactylus. Curves of (A) growth in length $\left(\mathrm{SL}=2.87\left[1-\mathrm{e}^{70.11(\mathrm{t}+1.64)}\right]\right.$ for males and $\mathrm{SL}=2.18\left[1-\mathrm{e}^{-0.29(\mathrm{t}+1.22)}\right]$ for females); (B) growth in weight $\left(\mathrm{W}=0.188\left[1-\mathrm{e}^{-0.11(\mathrm{t}+1.64)}\right]^{3.34}\right.$ for males and $\mathrm{W}=0.075\left[1-\mathrm{e}^{-0.29(t+1.22)}\right]^{3.42}$ for females); and $(\mathrm{C})$ growth rate $\left(V_{T}\right)$ of the total of individuals collected from Anchieta Island.

with an increase of this percentage in the next size-classes. A very low number of immature individuals was found, although there was a greater abundance of small specimens every three months which showed a continuous recruitment.

In relation to growth, seven and five cohorts coexisting at the same time were observed for males and females, respectively. Males presented larger asymptotic length $\left(\mathrm{L}_{\infty}=2.87 \mathrm{~mm}\right)$ and weight $\left(\mathrm{W}_{\infty}=0.188 \mathrm{~g}\right)$ and smaller growth constant $(\mathrm{K}=0.11)$ than females $\left(\mathrm{L}_{\infty}=2.18 \mathrm{~mm} ; \mathrm{W}_{\infty}=0.075 \mathrm{~g} ; \mathrm{K}=0.29\right)$ (Figure 1).

The individuals attained the morphological sexual maturity (based on the smallest ovigerous female, $\mathrm{SL}=1.06 \mathrm{~mm}$ ) at approximately 2 and 3.5 months for females and males, respectively, and from this age there was a marked weight gain for both sexes (Figure 1). Female growth was faster than males at the start of the life span, and reached the asymptotic length faster than males (approximately 18 months for females and 24 for males).

The mean size of the individuals in the present study was smaller than the size observed for the same species by Negreiros-Fransozo et al. (1991). The difference among mean size of individuals for the same species, from different areas, has been reported for other hermit crabs (Manjón-Cabeza \& García Raso, 1994) and can be influenced by utilization of shells, predation, diet, competition and parasitism. Furthermore, the high density and abundance of this and other hermit crab species coexistent in the same area (Mantelatto \& Garcia, 2002) may promote competition by resources (Mantelatto \& Meireles, 2004) and influence the size of individuals of this population (Manjón-Cabeza \& García Raso, 1994).

Pagurus brevidactylus exhibited sexual dimorphism that is important in selective pressure as intra- and interspecific fights for food, copulation, territory and shell. The females reached sexual maturity earlier than males (approximately 2 and 3.5 months, respectively) in the life span. This fact emphasizes the intense reproduction of $P$. brevidactylus, starting within the first months of life. Females were captured in larger numbers, reached smaller maximum size and showed larger growth rates than males during the initial stages of the life cycle. Therefore a larger number of females growing faster in a shorter time than males, promoted an accumulation of females in the initial sizeclasses and consequently the variation of sex ratio from 1:1 in these classes. The proportion of males clearly increased with larger sizes and influenced the sex ratio in function at size.

Pagurus brevidactylus exhibited longevity of approximately 24 months for males and 18 months for females, which is similar to observed populations of other hermit crabs at similar sizes, such as 24 to 27 months for the diogenid Diogenes pugilator (ManjónCabeza \& García Raso, 1998) and 21 months for the pagurid Cestopagurus timidus (Manjón-Cabeza \& García Raso, 1994). Many differences observed in life phases for males and females can be related to habitat, pollution, food, shell utilization, stresses and size of animals. However, the present study demonstrated a well established population in Anchieta Island.

This work is part of a MSc thesis (Curso de Pós-Graduação em Ciências, Biologia Comparada da FFCLRP/USP) by R.A.C. and was supported by a scholarship (Proc. 99/11680-3) and research grants to F.L.M. (Proc. 98/07454-5) from FAPESP and $\mathrm{CNPq}$ (Research Scholarship). We thank the Secretaria do Meio Ambiente do Estado de São Paulo, IBAMA and Parque Estadual da Ilha Anchieta for permission (Proc. 42358/98). Special thanks are due to many colleagues from the Laboratory of Bioecology and Systematic of Crustaceans, FFCLRP/USP who helped with sampling and laboratory analysis. We also thank R. Shimizu (USP), G. Bond-Buckup (UFRGS), and anonymous referees for helpful criticism and suggestions during the first version of this manuscript.

\section{REFERENCES}

Manjón-Cabeza, M.E. \& García Raso, J.E., 1994. Estructura de una población del cangrejo ermitaño Cestopagurus timidus (Crustacea: Decapoda: Anomura) de fondos de Posidonia oceanica del SE de Espana. Cahiers de Biologie Marine, 35, 225-236.

Manjón-Cabeza, M.E. \& García Raso, J.E., 1998. Population structure and growth of the hermit crab Diogenes pugilator (Decapoda: Anomura: Diogenidae) from the north-eastern Atlantic. Journal of Crustacean Biology, 18, 753-762.

Mantelatto, F.L. \& Garcia, R.B., 2002. Hermit crab fauna from the infralittoral of Anchieta Island (Ubatuba, Brazil). In Modern approaches to the study of Crustacea research (ed. E.E. Briones and F. Alvarez), pp. 137-144. New York: Kluwer Academic/Plenum Publishers.

Mantelatto, F.L. \& Meireles, A.L., 2004. The importance of shell occupation and shell availability in the hermit crab Pagurus brevidactylus (Stimpson, 1859) (Paguridae) population from the southern Atlantic. Bulletin of Marine Science, 75, 27-35.

Negreiros-Fransozo, M.L., Fransozo A. \& Hebling, N.J., 1991. Estrutura populacional e determinação do tamanho da concha em quatro espécies de ermitões (Crustacea, Decapoda, Anomura) do litoral paulista. Biotemas, 4, 135-148.

Valenti, W.C., Mello, J.T.C. \& Castagnolli, N., 1993. Efeito da densidade populacional sobre as curvas de crescimento de Macrobrachium rosembergii (De Man) em cultivo semi-intensivo (Crustacea, Palaemonidae). Revista Brasileira de Zoologia, 10, $427-438$.

Submitted 8 October 2003. Accepted 8 December 2004. 